\title{
ZSWIM4 wt Allele
}

National Cancer Institute

\section{Source}

National Cancer Institute. ZSWIM4 wt Allele. NCI Thesaurus. Code C150356.

Human ZSWIM4 wild-type allele is located in the vicinity of 19p13.13 and is approximately $37 \mathrm{~kb}$ in length. This allele, which encodes zinc finger SWIM domain-containing protein 4, plays a role in zinc binding. 